\title{
ANALISIS PERHITUNGAN ASET DAN LIABILITAS BERDASARKAN PENILAIAN STANDAR AKUNTANSI KEUANGAN DAN PRAKTEK AKUNTANSI ASURANSI PADA PT ASURANSI JIWA MEGA LIFE
}

\author{
Siti Nurlatifah \\ Program Studi Akuntansi, Fakultas Ekonomi Universitas Krisnadwipayana \\ Kampus Unkris Jatiwaringin \\ email: ifa.latifah.unkris915@gmail.com
}

\begin{abstract}
This research aims to (1) determine the amount of the difference between GAAP (Generally Accepted Accounting Principles) and SAP (Standar Accounting Practices) assessment and the amount of assets that are not allowed in the calculation of assets, (2) determine the amount of the difference between GAAP and SAP ratings in the calculation of liabilities PT Asuransi Jiwa Mega Life period in 2016 and (3) determine the value Risk Based Capital (RBC) associated with the achievement of the solvency ratio of PT Asuransi Jiwa Mega Life period in 2016. The research found that (1) the largest amount of funds needed to anticipate the risk of loss that may arise as a result of the deviation in the management of assets and liabilities is at Risk Liability Insurance (Schedule D) that is equal to 49.90\% (Rp. 26,445.87 million) of the total number of RBC Rp. 52,996.63 million (2) the achievement of the solvency ratio achieved by the Life Insurance Company Megalife period of 2016 by $670 \%$, meaning that if all customers to make a claim, the insurance company can meet all of its liabilities and still have a reserve of $570 \%$.
\end{abstract}

Keywords:Assets, Liabilities, RBC, GAAP, SAP.

\section{PENDAHULUAN}

Perusahaan asuransi merupakan salah satu lembaga keuangan non bank yang bergerak dalam bidang jasa keuangan yang dapat dijadikan sebagai satu pilar perekonomian di Indonesia, karena perkembangan perusahaan asuransi telah memberikan pengaruh pada kondisi dan pertumbuhan ekonomi.

Perusahaan asuransi, khususnya asuransi jiwa mempunyai karakteristik yang berbeda dengan jenis usaha jasa keuangan pada umumnya, dikarenakan usaha ini menerima pengalihan berbagai macam risiko dari pihak lain dan memberikan proteksi yang bersifat jangka panjang kepada nasabah, sehingga diperlukan pengelolaan risiko yang komprehensif (menyeluruh) dan pandangan mengenai proyeksi masa yang akan datang. Selain itu, dikarenakan dalam kegiatan operasionalnya perusahaan asuransi mengumpulkan dana masyarakat dalam bentuk premi asuransi, maka kegiatan usahanya pun diawasi dan diatur oleh Pemerintah.
Perusahaan asuransi harus mematuhi berbagai peraturan perundangan yang telah ditetapkan di masing-masing negara di mana perusahaan asuransi tersebut beroperasi. Tujuan utama dari adanya peraturan perundangan tersebut adalah untuk mengatur agar perusahaan asuransi melakukan kegiatan usahanya secara jujur dan etis tanpa merugikan masyarakat selaku nasabah atas jasa keuangan yang dipasarkan. Perusahaan harus mempunyai kemampuan dari segi keuangan untuk memenuhi semua kewajiban baik jangka pendek maupun jangka panjang tepat pada waktunya. Oleh karenanya perusahaan asuransi dituntut untuk memiliki kinerja keuangan yang sehat dan stabil baik untuk saat ini maupun untuk masa-masa yang akan datang yang merupakan salah satu faktor penting dari penilaian atas perusahaan asuransi itu sendiri.

Dalam industri asuransi, pengetahuan tentang kondisi keuangan sebuah perusahaan asuransi menjadi salah satu faktor penting. Hal ini disebabkan karena, perusahaan asuransi yang memasarkan jasa keuangannya yaitu berupa jaminan atas kerugian yang harus ditanggung karena terjadinya risiko-risiko bahaya yang dijamin dalam sebuah polis. Kepercayaan para nasabah kepada perusahaan 
asuransi dilandasi oleh faktor kesehatan keuangan dari perusahaan asuransi itu sendiri. Di mana, secara khusus sebuah perusahaan asuransi dapat memberikan ganti rugi atas kerugian yang diderita oleh nasabahnya, dan secara umumnya dapat memenuhi seluruh kewajibannya melalui bukti bahwa kondisi keuangan perusahaan asuransi tersebut cukup sehat dalam menjalankan usahanya dengan memiliki aset dan kekuatan modal melebihi dari total kewajiban yang dimilikinya.

Berdasarkan data yang telah dijelaskan di atas, salah satu hal pokok yang dapat diamati adalah solvabilitas perusahaan asuransi. Solvabilitas suatu perusahaan menunjukkan kemampuan perusahaan untuk memenuhi kewajiban keuangannya baik jangka pendek maupun jangka panjang apabila sekiranya perusahaan dilikuidasi. Suatu perusahaan yang solvable berarti bahwa perusahaan tersebut mempunyai aktiva atau kekayaan yang cukup untuk membayar semua hutang-hutangnya, begitu pula sebaliknya perusahaan yang tidak mempunyai kekayaan yang cukup untuk membayar hutanghutangnya disebut perusahaan yang insolvable.

Tingkat solvabilitas perusahaan asuransi di Indonesia ditentukan dengan nilai Risk Based Capital (RBC). Risk Based Capital merupakan salah satu metode pengukuran batas tingkat solvabilitas yang dipersyaratkan dalam peraturan perundangan dalam mengukur tingkat kesehatan keuangan sebuah perusahaan asuransi untuk memastikan pemenuhan kewajiban perusahaan dengan mengetahui besarnya kebutuhan modal perusahaan sesuai dengan tingkat risiko yang dihadapi perusahaan dalam mengelola kekayaan dan kewajibannya. RBC ini, diperoleh dari hasil dengan membandingkan selisih kekayaan yang diperkenankan dan kewajiban dengan modal minimum berbasis risiko.

Untuk melindungi masyarakat sebagai pengguna jasa asuransi dan dalam rangka pengawasan dan pembinaan industri asuransi, pemerintah memberlakukan ketentuanketentuan tentang kesehatan keuangan dan target tingkat solvabilitas perusahaan asuransi dan reasuransi. Berdasarkan Peraturan Menteri Keuangan No.53/PMK.10/2012 diterangkan bahwa setiap perusahaan asuransi wajib menetapkan target tingkat solvabilitas setiap tahunnya paling rendah sebesar $120 \%$ (seratus dua puluh persen) dari Modal Minimum
Berbasis Risiko (MMBR). Modal Minimum Berbasis Risiko adalah jumlah dana yang dibutuhkan untuk mengantisipasi risiko kerugian yang mungkin timbul sebagai akibat dari deviasi dalam pengelolaan aset dan liabilitas.

Penilaian atas kesehatan keuangan sangat diperlukan, selain untuk memberikan gambaran atau prediksi kelangsungan hidup perusahaan dalam jangka waktu panjang juga untuk menilai kinerja suatu perusahaan asuransi, baik untuk kepentingan manajemen, pemegang polis sebagai pihak tertanggung, investor, dan pemerintah. Karena semakin baik citra perusahaan yang dimiliki maka semakin dapat menarik minat masyarakat agar membeli produk asuransi dan banyak investor yang menanamkan modalnya di perusahaan tersebut.

\section{TINJAUAN PUSTAKA}

\section{Definisi Asuransi}

Berdasarkan Undang-undang No. 40 tahun 2014 Pasal 1 mendefinisikan asuransi sebagai berikut, "Asuransi adalah perjanjian antara dua pihak, yaitu perusahaan asuransi dan pemegang polis, yang menjadi dasar bagi penerimaan premi oleh perusahaan asuransi sebagai imbalan untuk :

a. Memberikan penggantian kepada tertanggung atau pemegang polis karena kerugian, kerusakan, biaya yang timbul, kehilangan keuntungan, atau tanggungjawab hukum kepada pihak ketiga yang mungkin diderita tertanggung atau pemegang polis karena terjadinya suatu peristiwa yang tidak pasti, atau

b. Memberikan pembayaran yang didasarkan pada meninggalnya tertanggung atau pembayaran yang didasarkan pada hidupnya tertanggung dengan manfaat yang besarnya telah ditetapkan dan/atau didasarkan pada hasil pengelolaan dana.

Pengertian pada point a. lebih dikenal sebagai asuransi umum atau kerugian sedangkan pengertian $b$. lebih dikenal sebagai asuransi jiwa.

\section{Standar Akuntansi Keuangan(SAK) dan Statutory Accounting Practise(SAP)}

Secara umum, Standar Akuntansi

Keuangan (SAK) adalah suatu kerangka dalam prosedur pembuatan laporan keuangan agar terjadi keseragaman dalam penyajian laporan 
keuangan. Standar Akuntansi Keuangan (SAK) merupakan hasil perumusan Komite Prinsipil Akuntansi Indonesia pada tahun 1994 menggantikan Prinsip Akuntansi Indonesia tahun 1984.

SAK di Indonesia merupakan terapan dari beberapa standar akuntansi yang ada seperti, IAS, IFRS, ETAP, GAAP. Selain untuk keseragaman laporan keuangan, Standar akuntansi juga diperlukan untuk memudahkan penyusunan laporan keuangan, memudahkan auditor serta Memudahkan pembaca laporan keuangan untuk menginterpretasikan dan membandingkan laporan keuangan entitas yang berbeda.

Sedangkan berdasarkan Surat Edaran OJK No. 2/SEOJK.05/2012, Lampiran II tentang Petunjuk Penyusunan Laporan Keuangan Perusahaan Asuransi Jiwa, Statutory Accounting Practice (SAP) merupakan laporan keuangan yang dibuat khusus untuk kepentingan pembinaan dan pengawasan usaha perasuransian, sehingga bentuk, isi, dan susunan laporan keuangan dibuat sesuai dengan ketentuan perundangundangan yang berlaku di bidang usaha perasuransian, sebagaimana diatur dalam Peraturan Menteri Keuangan Nomor 53 Tahun 2012 dan peraturan pelaksanaannya.

Berdasarkan Surat Edaran OJK No. 2/SEOJK.05/2012, Lampiran II ada beberapa perbedaan antara SAK dan SAP, yaitu sebagai berikut :

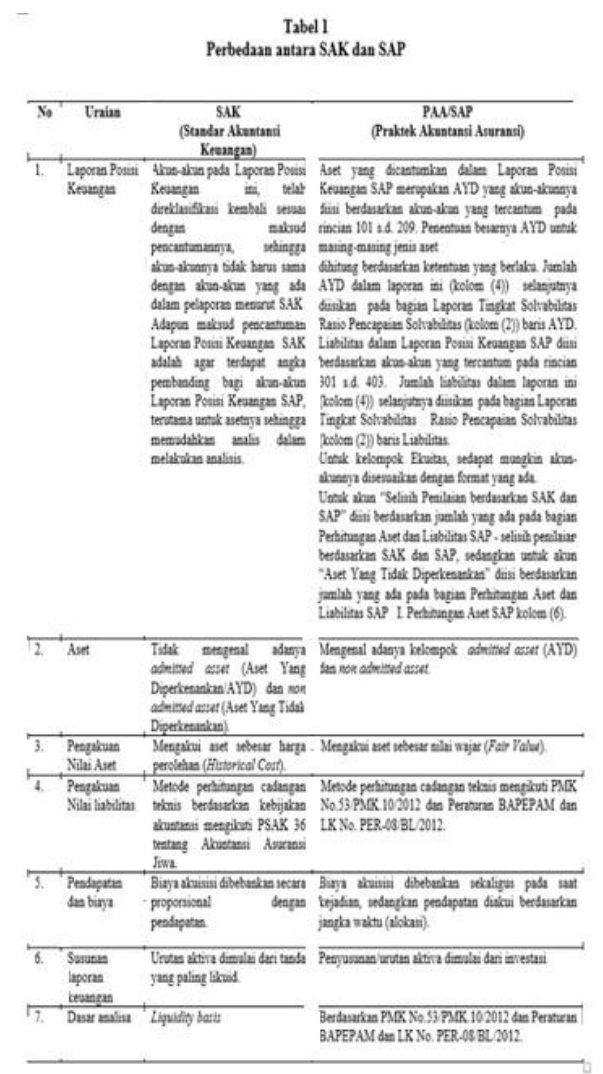

\section{Komponen Rasio Pencapaian Solvabilitas (RBC)}

Rasio kesehatan Risk Based Capital adalah suatu ukuran yang menginformasikan tingkat keamanan finansial atau kesehatan suatu perusahaan asuransi yang harus dipenuhi oleh perusahaan asuransi dan reasuransi minimum sebesar $120 \%$ (seratus dua puluh persen) dari Modal Minimum Berbasis Risiko (MMBR). Semakin besar rasio kesehatan Risk Based Capital sebuah perusahaan asuransi, semakin sehat kondisi financial perusahaan tersebut.

Komponen yang dipakai untuk mengukur RBC mengacu kepada Peraturan Menteri Keuangan No.53/PMK.010/2012 yaitu tentang kesehatan Keuangan perusahaan asuransi dan reasuransi.

Komponen-komponen tersebut adalah sebagai berikut :

\section{a. Tingkat Solvabilitas}

Untuk perhitungan tingkat solvabilitas, terdiri dari komponen-komponen :

1) Aset Yang Diperkenankan (AYD)

Mengacu kepada Peraturan Menteri

Keuangan No.53/PMK.010/2012, maka Kekayaan yang diperkenankan yang diperhitungkan dalam perhitungan tingkat solvabilitas adalah sebagai berikut :

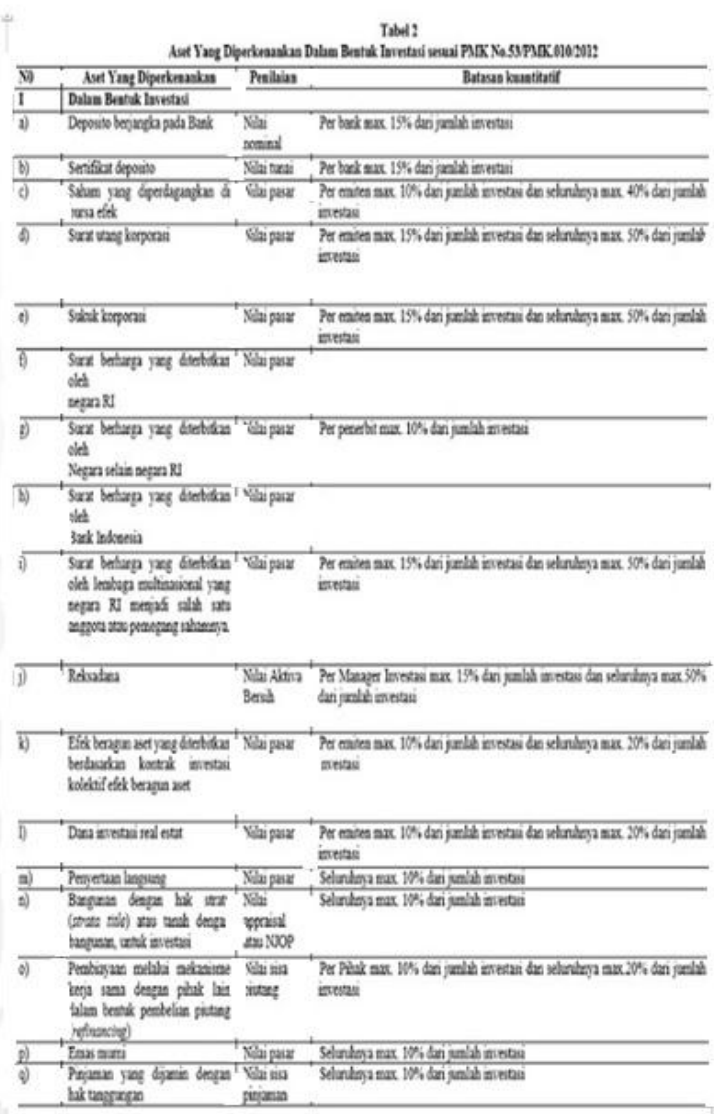


Tabel 3

Aset Yang Diperkenankan Dalam Bentuk Non Investasi sesuai PMK No.53/PMK.010/2012

\begin{tabular}{|c|c|c|c|}
\hline No & Aset Yang Diperkenankan & Penilaian & Batasan Kualitatif \\
\hline II & Dalam Bentuk Non Investas & & \\
\hline a) & Kas dan Bank & Nilai nominal & $\begin{array}{l}\text { Luar Negeri : max. } \\
1 \% \text { dari ekuitas }\end{array}$ \\
\hline b) & $\begin{array}{l}\text { Tagihan premi penutupan } \\
\text { langsung, termasuk tagihan } \\
\text { premi koasuransi yang } \\
\text { menjadi bagi perusahaan }\end{array}$ & Nilai sisa tagihan & Max. 2 bulan \\
\hline c) & Tagihan klaim koasuransi & Nilai sisa tagihan & Max. 2 bulan \\
\hline d) & Tagihan reasuransi & Nilai sisa tagihan & Max. 2 bulan \\
\hline e) & Tagihan investasi & Nilai sisa tagihan & Max. 1 bulan \\
\hline f) & Tagihan hasil investasi & Nilai sisa tagihan & Max. 1 bulan \\
\hline g) & Pinjaman polis & Nilai sisa pinjaman & $\begin{array}{l}\text { Max. } 80 \% \text { dari } \\
\text { nilai tunai polis }\end{array}$ \\
\hline h) & $\begin{array}{l}\text { Bangunan dengan hak strata } \\
\text { (strata title) atau tanah } \\
\text { dengan bangunan, untuk } \\
\text { dipakai sendiri }\end{array}$ & $\begin{array}{lr}\text { Nilai } & \text { yang } \\
\text { ditetapkan } & \text { Lembaga } \\
\text { penilai } & \text { yang } \\
\text { terdaftar } & \text { pada } \\
\text { instansi } & \text { yang } \\
\text { berwenang } & \text { atau } \\
\text { Nilai Jual } & \text { Objek } \\
\text { Pajak (NJOP) } & \end{array}$ & $\begin{array}{l}\text { Max. } 15 \% \text { dari } \\
\text { ekuitas }\end{array}$ \\
\hline
\end{tabular}

2) Liabilitas (tidak termasuk pinjaman subordinasi)

Mengacu kepada Peraturan Menteri Keuangan No.53/PMK.010/2012, Liabilitas yang diperhitungkan dalam perhitungan tingkat solvabilitas selain pinjaman subordinasi adalah sebagai berikut :

a) Liabilitas dalam bentuk Cadangan Teknis, terdiri dari komponen :

(1) Cadangan premi untuk produk yang berjangka waktu lebih dari 1 (satu) tahun yang syarat dan kondisi polisnya tidak dapat diperbaharui kembali (non renewable) pada setiap ulang tahun polis

(2) Cadangan atas premi yang belum merupakan pendapatan untuk produk yang berjangka waktu sampai dengan 1 (satu) tahun atau berjangka waktu lebih dari 1 (satu) tahun yang syarat dan kondisi polisnya dapat diperbaharui kembali (renewable) pada setiap ulang tahun polis

(3) Cadangan akumulasi dana untuk produk atau bagian dari produk yang memberikan manfaat berupa akumulasi dana

(4) Cadangan klaim

\section{b. Modal Minimum Berbasis Risiko (MMBR)}

Untuk perhitungan Modal Minimum Berbasis Risiko, mengacu pada Peraturan Ketua Bapepam dan LK, No.PER-
08/BL/2012. Komponen-komponen MMBR terdiri dari:

Schedule A (Risiko kegagalan
pengelolaan aset)
Skedul yang menggambarkan risiko kegagalan pengelolaan aset yang timbul dari kemungkinan adanya kehilangan atau penurunan nilai aset yang disebabkan oleh faktor risiko pasar atau risiko kredit.

Jumlah dana yang dibutuhkan untuk menanggulangi risiko tersebut ditentukan dengan mengalikan faktor risiko (fr) untuk jenis aset tersebut dengan nilai AYD yang dapat digambarkan dengan rumus berikut :

\section{Jumlah dana $=\mathbf{\Sigma}\left(\mathbf{f r}_{\mathbf{i}} \times \mathbf{A Y D _ { \mathbf { i } }}\right)$}

Mengenai ketentuan Peringkat yang digunakan, faktor risiko (fr) untuk setiap jenis Aset serta contoh perhitungan beban modal untuk masing-masing jenis aset investasi mengacu pada lampiran 1 (satu) yaitu Peraturan Ketua Bapepam dan LK, No.PER08/BL/2012.

2) Schedule B (Risiko ketidakseimbangan antara proyeksi arus aset dan liabilitas)

Skedul yang menggambarkan Risiko Ketidakseimbangan antara proyeksi Arus Aset dan Liabilitas (RKAAL) yang timbul karena adanya ketidaksesuaian antara besar dan saat jatuh tempo liabilitas dengan besar dan saat jatuh tempo asset. Untuk menghitung Schedule B, nilai AYD dan liabilitas mengacu pada nilai buku pada laporan posisi keuangan, dikelompokkan berdasarkan saat jatuh temponya (maturity), yaitu :

a) Jatuh tempo dalam jangka waktu kurang dari 1 (satu) tahun;

b) Jatuh tempo dalam jangka waktu lebih dari 1 (satu) tahun tetapi kurang dari 3 (tiga) tahun;

c) Jatuh tempo dalam jangka waktu lebih dari 3 (tiga) tahun tetapi kurang dari 5 (lima) tahun;

d) Jatuh tempo dalam jangka waktu lebih dari 5 (lima) tahun tetapi kurang dari 10 (sepuluh) tahun; dan

e) Jatuh tempo dalam jangka waktu 10 (sepuluh) tahun atau lebih.

AYD berupa efek yang diperdagangkan dan dinilai berdasarkan nilai pasar (antara lain saham) diklasifikasikan sebagai aset yang jatuh tempo dalam jangka waktu kurang dari 1 (satu) tahun. AYD yang bertujuan untuk 
dimiliki sampai dengan jatuh tempo diklasifikasikan sesuai dengan sisa umurnya.

Jumlah dana yang dibutuhkan untuk menanggulangi RKAAL tersebut dihitung sebagai berikut :

\section{RKKAL $=\Sigma 4,0 \% \times\left(\operatorname{Max}\left(L_{-}-A_{1} D_{i}\right), 0\right)$}

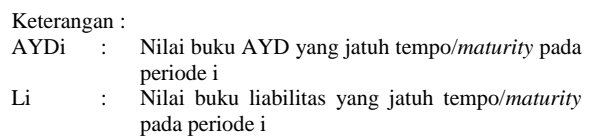

3) Schedule C (Risiko ketidakseimbangan antara nilai aset dan liabilitas dalam setiap jenis mata uang asing)

Skedul yang menggambarkan risiko ketidakseimbangan antara nilai aset dan liabilitas dalam setiap jenis mata uang asing (RKMA) yang timbul karena adanya perbedaan nilai aset dan liabilitas dalam mata uang asing serta fluktuasi nilai tukar mata uang asing terhadap rupiah.

Jumlah dana yang dibutuhkan untuk menanggulangi risiko tersebut dihitung sebagai berikut :

Tabel 4

Jumlah dana yang dibutuhkan untuk menanggulangi Schedule C

\begin{tabular}{ccc}
\hline AYD & Faktor & RKMA \\
\hline Kurang dari atau sama dengan nol & $30 \%$ & $\Sigma 30 \% \times \mathrm{L}_{\mathrm{i}}-\mathrm{AYD}_{\mathrm{i}}$
\end{tabular}

\begin{tabular}{lcc}
\hline $\begin{array}{l}\text { Lebih dari nol namun tidak melebihi } \\
20 \% \text { dari Jumlah Kewajiban }\end{array}$ & $0 \%$ & Nol \\
\hline $\begin{array}{l}\text { Melebihi 20\% dari Jumlah } \\
\text { Kewajiban }\end{array}$ & $10 \%$ & $10 \% \times \Sigma\left(\mathrm{AYD}_{\mathrm{i}}-\left(120 \% \mathrm{x} \mathrm{L}_{\mathrm{i}}\right)\right.$
\end{tabular}

(Sumber : Diolah penulis, 2017)

Keterangan :

AYDi : Nilai buku AYD mata uang

$\mathrm{Li} \quad$ Nilai buku liabilitas mata uang

4) Schedule D (Risiko perbedaan antara Beban Klaim yang terjadi dan Beban Klaim yang diperkirakan)

Skedul yang menggambarkan risiko perbedaan antara beban klaim yang terjadi dan beban klaim yang diperkirakan (selanjutnya disebut Risiko Liabilitas Asuransi atau RLA) yang timbul dari kemungkinan pengalaman klaim yang terjadi lebih buruk dari pada klaim yang diperkirakan dan perhitungan cadangan teknis yang terlalu rendah.

Perhitungan RLA untuk produk asuransi yang berjangka waktu lebih dari 1 (satu) tahun yang syarat dan kondisi polisnya tidak dapat diperbaharui kembali (non renewable) pada setiap ulang tahun polis atau Schedule D1, ditentukan dengan menggunakan formula sebagai berikut :

$$
\text { RLA = max }((C P *-C P), 0)
$$

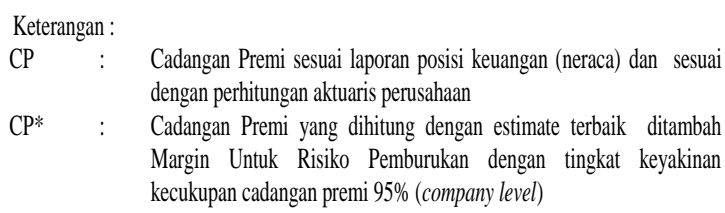

Perhitungan RLA untuk produk asuransi yang berjangka waktu sampai dengan 1 (satu) tahun atau berjangka waktu lebih dari 1 (satu) tahun yang syarat dan kondisi polisnya dapat diperbaharui kembali (renewable) pada setiap ulang tahun polis atau Schedule D2, ditentukan dengan menggunakan formula sebagai berikut :

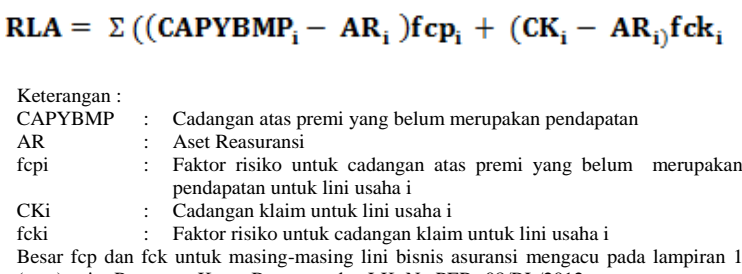

5) Schedule E (Risiko ketidakcukupan premi akibat perbedaan hasil investasi yang diasumsikan dalam penetapan premi dengan hasil investasi yang diperoleh)

Skedul yang menggambarkan risiko ketidakcukupan premi akibat perbedaan hasil investasi yang diasumsikan dalam penetapan premi dengan hasil investasi yang diperoleh yang timbul akibat tingkat hasil investasi yang diperoleh lebih rendah daripada tingkat hasil investasi yang diperkirakan dalam penetapan premi dan cadangan (selanjutnya disebut Risiko Tingkat Bunga atau RTB).

Jumlah dana yang dibutuhkan untuk menanggulangi RTB dihitung dengan formula

$$
\mathrm{RTB}=\mathrm{f}_{\mathrm{RTB}} \operatorname{Max}\left(\left(\mathrm{CP}_{\mathrm{rf}}-\mathrm{CP}_{\mathrm{o}}\right), \mathbf{0}\right)
$$


Keterangan :

fRTB : Faktor RTB

CPrf : Cadangan premi dihitung dengan bunga bebas risiko

CPo : Cadangan premi yang dihitung aktuaris perusahaan (cadangan premi yang disajikan di Laporan Posisi Keuangan/neraca)

6) Schedule F (Risiko ketidakmampuan pihak reasuradur untuk memenuhi liabilitas membayar klaim)

Skedul yang menggambarkan risiko ketidakmampuan pihak reasuradur untuk memenuhi liabilitas membayar klaim.

Jumlah dana yang diperhitungkan untuk menanggulangi risiko tersebut ditentukan dengan cara mengalikan besar eksposur reasuransi dengan faktor risiko. Besar eksposur reasuransi dihitung dari cadangan teknis beban penanggung ulang dikurangi deposit reasuradur yang berupa segala bentuk simpanan yang ditempatkan oleh reasuradur pada asuradur, termasuk premi yang ditahan oleh asuradur dimana asuradur memiliki otoritas penuh untuk menggunakan simpanan tersebut.

Faktor risiko yang digunakan untuk menanggulangi risiko reasuransi mengacu pada lampiran 1 (satu) yaitu Peraturan Ketua Bapepam dan LK, No.PER- 08/BL/2012.

7) Schedule G (Risiko kegagalan dalam proses produksi, ketidakmampuan SDM atau sistem untuk berkinerja dengan baik atau adanya kejadian lain yang merugikan)

Skedul yang menggambarkan risiko kegagalan dalam proses produksi, ketidakmampuan SDM atau sistem untuk berkinerja dengan baik atau adanya kejadian lain yang merugikan atau yang dikenal dengan Risiko Operasional (RO). Semakin komplek struktur perusahaan, Risiko Operasional akan meningkat. Proxy untuk kompleksitas operasional adalah besar Beban Umum dan Administrasi (BUA) setelah dikurangi Biaya Pendidikan dan Pelatihan (BPL). Besarnya faktor risiko operasional ditentukan sebagai berikut :

$$
\text { RO }=1 \%(B U A-B P L)
$$

8) Schedule H (Risiko kegagalan dalam proses produksi, ketidakmampuan SDM atau sistem untuk berkinerja dengan baik atau adanya kejadian lain yang merugikan berkaitan dengan pengelolaan dana investasi yang bersumber dari Produk Asuransi Yang
Dikaitkan Dengan Investasi (PAYDI))

Skedul yang menggambarkan risiko kegagalan dalam proses produksi, ketidakmampuan SDM atau sistem untuk berkinerja dengan baik atau adanya kejadian lain yang merugikan berkaitan dengan pengelolaan dana investasi yang bersumber dari PAYDI atau yang dikenal dengan risiko operasional PAYDI (ROPAYDI).

Jumlah dana yang diperhitungkan untuk menanggulangi risiko operasional PAYDI ditentukan dengan cara mengalikan besar dana kelolaan PAYDI perusahaan dengan faktor risiko operasional PAYDI, dengan formula sebagai berikut :

\section{ROPAYDI $=1 \% \times$ Dana kelolaan PAYDI}

Pedoman perhitungan MMBR untuk perusahaan asuransi yang menjual PAYDI dengan komponen investasi yang dijamin hasil minimumnya mengacu pada lampiran 1 (satu) Peraturan Ketua Bapepam dan LK, No.PER08/BL/2012.

Rasio pencapaian solvabilitas dari suatu perusahaan asuransi, khususnya perusahaan asuransi jiwa, mengacu kepada Peraturan Menteri Keuangan Republik Indonesia No.53/PMK.010/2012 mengatur tentang perhitungan tingkat solvabilitas dengan metode Risk Based Capital (RBC), diukur dengan menggunakan komponen-komponen berikut :

a. Jumlah Tingkat Solvabilitas

Untuk mengukur Jumlah Tingkat Solvabilitas suatu perusahaan asuransi jiwa, maka dapat dilakukan dengan menentukan Aset Yang Diperkenankan dikurangi Liabilitas (kecuali Pinjaman Subordinasi).

b. Modal Minimum Berbasis Risiko

Untuk mengukur Modal Minimum

Berbasis Risiko suatu perusahaan asuransi jiwa, maka dapat dilakukan dengan menjumlahkan dana yang dibutuhkan untuk mengantisipasi risiko kerugian yang mungkin timbul sebagai akibat dari deviasi dalam pengelolaan aset dan Liabilitas (schedule A sampai dengan schedule $\mathrm{H}$ ).

Adapun Model Perhitungan Risk Base Capital (RBC) yaitu sebagai berikut : 
Tabel 5

Model Perhitungan Risk Base Capital (RBC)

\begin{tabular}{|l|c|}
\hline \multicolumn{1}{|c|}{ Uraian } & Jumlah \\
\hline Tingkat Solvabilitas & \\
\hline a. Aset Yang Diperkenankan & $\mathrm{Xxx}$ \\
\hline b. Liabilitas (kecuali Pinjaman Subordinasi) & $\mathrm{Xxx}$ \\
\hline c. Jumlah Tingkat Solvabilitas (1a-1b) & $\mathrm{Xxx}$ \\
\hline 2. Modal Minimum Berbasis Risiko (MMBR) & \\
\hline a. Schedule A & $\mathrm{Xxx}$ \\
\hline b. Schedule B & $\mathrm{Xxx}$ \\
\hline c. Schedule C & $\mathrm{Xxx}$ \\
\hline d. Schedule D & $\mathrm{Xxx}$ \\
\hline e. Schedule E & $\mathrm{Xxx}$ \\
\hline f. Schedule F & $\mathrm{Xxx}$ \\
\hline g. Schedule G & $\mathrm{Xxx}$ \\
\hline h. Schedule H & $\mathrm{Xxx}$ \\
\hline i. Jumlah MMBR (2a+2b+2c+2d+2e+2f+2g+2h) & $\mathbf{X x x}$ \\
\hline 3. Kelebihan (Kekurangan) Batas Tingkat Solvabilitas (1c-2i) & $\mathbf{X x x}$ \\
\hline 4. Rasio Pencapaian Solvabilitas (dalam \%) (1c : 2i) & $\mathbf{X x x}$ \\
\hline (Sumber : Diolah penulis, 2017) & \\
\hline
\end{tabular}

\section{METODE PENELITIAN}

\section{Metode Penelitian}

Penelitian yang dilakukan adalah menggunakan pendekatan kuantitatif, yaitu penelitian yang informasi atau data yang digunakan harus terukur dan diharapkan dapat menghasilkan kesimpulan yang dapat digeneralisasikan. Sedangkan rancangan penelitian yang digunakan bersifat studi kasus dengan obyek penelitian yaitu PT Asuransi Jiwa Mega Life selama jangka waktu 1 tahun (periode 2016).

\section{Jenis dan Sumber Data}

Jenis data yang digunakan guna menyelesaikan penelitian ini berupa data sekunder yaitu data yang didapat dari sumber tertulis yang telah tersedia dan telah dikumpulkan dan dilaporkan oleh pihak lain. Sedangkan sumber data penelitian, diperoleh dari PT Asuransi Jiwa Mega Life berupa laporan keuangan perusahaan asuransi jiwa unit konvensional dalam bentuk laporan posisi keuangan (Neraca) non konsolidasi, perhitungan aset yang diperkenankan dan liabilitas SAP (Statutory Accounting Practice) non konsolidasi, perhitungan MMBR serta rasio pencapaian solvabilitas yang digunakan untuk proses analisis periode 2016.

\section{Metode Pengumpulan Data}

Metode pengumpulan data yang dilakukan, antara lain : a. Dokumentasi

Data yang digunakan dalam penelitian ini adalah data sekunder yang diperoleh dengan cara metode dokumentasi yaitu dengan mengutip langsung dari data dari laporan keuangan tahunan, dan website yang bersumber dari PT Asuransi Jiwa Mega Life periode 2016.

\section{b. Library Research}

Dilakukan dengan cara mengadakan studi kepustakaan untuk mempelajari literaturliteratur manajemen keuangan dan akuntansi yang berhubungan dengan masalah yang dibahas.

\section{Teknik Analisis Data}

Langkah-langkah yang dilakukan terhadap data yang diperoleh, adalah sebagai berikut :

a. Mencari dan mengklasifikasikan data berdasarkan jenisnya, yaitu data yang diperlukan untuk menghitung tingkat pencapaian solvabilitas PT Asuransi Jiwa Mega Life periode 2016, seperti :

1) Menentukan Jumlah Aset berdasarkan penilaian SAK dan SAP dalam Laporan Posisi Keuangan Bukan Konsolidasi

2) Menentukan Jumlah Liabilitas (selain pinjaman subordinasi) berdasarkan penilaian SAK dan SAP dalam Laporan Posisi Keuangan Bukan Konsolidasi

3) Menentukan nilai Modal Minimum Berbasis Risiko dalam Laporan Tingkat Solvabilitas PT Asuransi Jiwa Mega Life periode 2016.

b. Menganalisis perhitungan yang mempengaruhi tingkat pencapaian solvabilitas PT Asuransi Jiwa Mega Life periode 2016, yaitu :

1) Jumlah selisih penilaian SAK \& SAP dan jumlah aset yang tidak diperkenankan pada perhitungan Aset

2) Jumlah Selisih perhitungan liabilitas berdasarkan penilaian SAP dan SAK

3) Nilai MMBR terkait dengan rasio pencapaian solvabilitas PT Asuransi Jiwa Mega Life periode 2016.

\section{HASIL DAN PEMBAHASAN}

Hasil Penelitian adalah sebagai berikut : 
a. Dalam Analisis perhitungan aset berdasarkan penilaian SAK dan SAP terdapat beberapa aset yang mengalami selisih, dengan total selisih sebesar Rp. 121,101.23 juta. Adapun rinciannya :

1) Pada aset investasi, sebesar Rp. 43,984.86 juta meliputi :

- Pada Surat Utang Korporasi atas nama BLT Finance BV sebesar Rp. 5,674.28 juta. Hal ini terjadi karena peringkat yang dimiliki Surat Utang Korporasi tersebut di bawah peringkat $\mathrm{BBB}$ yang telah diatur di dalam PMK No.53/PMK.010/2012.

- Surat Berharga yang Diterbitkan oleh Negara RI atas nama FR 0026, FR 0028, FR 0040, FR 0043, FR 0044, FR 004, FR 0047, FR 0048 sebesar Rp. 10,509.85 juta. Hal ini terjadi, karena nilai buku dari beberapa surat berharga tersebut dalam penilaian SAK lebih kecil dibandingkan nilai pasar dalam penilaian SAP.

- Bangunan dengan Hak Strata atau Tanah dengan Bangunan untuk Investasi sebesar Rp. 300.73 juta. Hal ini terjadi, karena Biaya perolehan dari properti investasi tersebut dalam penilaian SAK lebih kecil dibandingkan nilai apraisal dalam penilaian SAP.

- Investasi Lain sebesar Rp. 27,500 juta. Hal ini terjadi, karena aset ini tidak dimasukkan sebagai aset yang diperkenankan dalam perhitungan tingkat solvabilitas sebagaimana yang telah diatur di dalam PMK No.53/PMK.010/2012.

2) Pada aset bukan investasi, sebesar Rp. 77,116.37 juta meliputi :

- Tagihan premi penutupan langsung sebesar Rp. 33,633.68 juta. Hal ini terjadi karena dalam penilaian SAP, nilai yang diakui sebagai AYD atau yang menjadi sisa tagihan kurang atau sama dengan 2 (dua) bulan sebagaimana yang telah diatur di dalam PMK No.53/PMK.010/2012 yaitu sebesar Rp. 12,890.69 juta.

- Untuk aset tetap lain terdapat aset yang tidak diperken ankan sebesar Rp. 2,764.87 juta dan untuk aset lain sebesar Rp. 40,717.82 juta. Hal ini terjadi karena dalam penilaian SAP yang mengacu pada PMK No.53/PMK.010/2012,tidak memasukan tersebut sebagai aset yang diperkenankan dalam perhitungan tingkat solvabilitas.

$$
\text { Tabel } 6
$$

\begin{tabular}{|c|c|c|c|c|c|}
\hline \multirow[b]{2}{*}{ No. } & \multicolumn{5}{|c|}{ (Dalam jutaan rupiah) } \\
\hline & Aset & $\begin{array}{l}\text { Saldo } \\
\text { Buku } \\
\text { Besar } \\
\text { (SAK) }\end{array}$ & $\begin{array}{c}\text { Aset Yang } \\
\text { Diperkenanka } \\
\text { n (Saldo SAP) }\end{array}$ & $\begin{array}{c}\text { Selisih } \\
\text { penilaian } \\
\text { SAP \&SAK }\end{array}$ & $\begin{array}{c}\text { Aset yang } \\
\text { tidak } \\
\text { diperkenanka } \\
\text { n }\end{array}$ \\
\hline I & \multicolumn{5}{|c|}{ Dalam Bentuk Investasi } \\
\hline 1. & $\begin{array}{lr}\text { Surat } & \text { Utang } \\
\text { Korporasi } & \text { dan } \\
\text { Sukuk Korporasi }\end{array}$ & $249,348.99$ & $243,674.71$ & $(5,674.28)$ & \\
\hline 2. & $\begin{array}{l}\text { Surat Berharga } \\
\text { yang Diterbitkan } \\
\text { oleh Negara RI }\end{array}$ & $322,705.78$ & $333,215.64$ & $10,509.85$ & \\
\hline 3. & $\begin{array}{l}\text { Bangunan dengan } \\
\text { Hak Strata atau } \\
\text { Tanah dengan } \\
\text { Bangunan untuk } \\
\text { Investasi }\end{array}$ & $9,299.27$ & $9,600.00$ & 300.73 & \\
\hline 4. & Investasi Lain & $27,500.00$ & - & $(27,500.00)$ & \\
\hline II & Dalam Bentuk Non & Investasi & & & \\
\hline 5. & $\begin{array}{ll}\text { Tagihan } & \text { Premi } \\
\text { Penutupan } & \\
\text { Langsung } & \end{array}$ & $46,524.37$ & $12,890.69$ & - & $(33,633.68)$ \\
\hline 6. & Aset Tetap Lain & $2,764.87$ & - & & $(2,764.87)$ \\
\hline 7. & Aset Lain & $40,717.82$ & - & & $(40,717.82)$ \\
\hline & JUMLAH & 698,861,1 & $599,381.04$ & $(22,363.70)$ & $(77,116.37)$ \\
\hline
\end{tabular}

b. Dalam Analisis perhitungan liabilitas berdasarkan penilaian SAK dan SAP terdapat liabilitas yang mengalami selisih, yaitu :

- Cadangan Premi sebesar Rp. 44,145 juta. Hal ini terjadi karena dalam penilaian SAK, pembentukan cadangan premi dihitung dengan menggunakan asumsi estimasi terbaik dari penerimaan dan pengeluaran yang dapat terjadi di masa yang akan datang tanpa ditambah marjin untuk risiko 
pemburukan (Margin for Adverse

Deviation). Sedangkan dalam penilaian SAP yang mengacu pada PMK No.53/PMK.10/2012, dihitung dengan menggunakan asumsi estimasi terbaik dari penerimaan dan pengeluaran yang dapat terjadi di masa yang akan datang dengan ditambah marjin untuk risiko pemburukan (Margin for Adverse Deviation).

Tabel 7

Selish Penilaian SAP dan SAK untuk Perhitungan Liabilitas

\begin{tabular}{cccc} 
& & & (Dalam jutaan rupiah) \\
\hline Liabilitas & Saldo Buku & Penilaian & Selisih penilaian \\
& Besar (SAK) & Berdasarkan & SAP dan SAK \\
& & SAP &
\end{tabular}

\begin{tabular}{llll}
\hline Cadangan Premi & $398,493.79$ & $442,638.52$ & $(44,145)$ \\
\hline JUMLAH & $\mathbf{3 9 8 , 4 9 3 . 7 9}$ & $\mathbf{4 4 2 , 6 3 8 . 5 2}$ & $\mathbf{( 4 4 , 1 4 5 )}$
\end{tabular}

(Sumber : Laporan Keuangan PT. Asuransi Jiwa Mega Life periode 2016)

c. Dalam analisis nilai Modal Minimum Berbasis Risiko (MMBR) yang terkait dengan perhitungan rasio pencapaian solvabilitas, maka ditemukan hasil penelitian bahwa :

1) Jumlah dana terbesar yang dibutuhkan untuk mengantisipasi risiko kerugian yang mungkin timbul sebagai akibat deviasi dalam pengelolaan aset dan liabilitas adalah pada Risiko Liabilitas Asuransi (Schedule D) yaitu sebesar 49,90\% (Rp. 26,445.87 juta) dari total jumlah MMBR sebesar Rp. 52,996.63 juta. Kemudian diikuti Risiko Pengelolaan Aset (Schedule A) sebesar 23,12\% (Rp. 12,254.45 juta), Risiko Ketidakseimbangan Mata Uang Asing (Schedule C) sebesar 10,80\% (Rp. 5,724.03 juta), Risiko Ketidakseimbangan Antara Proyeksi Arus Aset dan Liabilitas (Schedule B) sebesar 9,54\% (Rp. 5,057.99 juta), Risiko Reasuransi (Schedule F) sebesar 4,95\% (Rp. 2,621.79 juta), Risiko Operasional (Schedule G) sebesar 1,13\% (Rp. 601.33 juta) dan Risiko Operasional PAYDI (Schedule H) sebesar 0,55\% (Rp. 291,19 juta) dari total jumlah MMBR sebesar Rp. 52,996.63 juta.

2) Rasio pencapaian solvabilitas yang dicapai oleh Perusahaan Asuransi Jiwa Megalife periode 2016 sebesar 670\%, artinya apabila seluruh nasabah mengajukan klaim, maka perusahaan asuransi dapat memenuhi seluruh kewajibannya dan masih mempunyai cadangan sebesar $570 \%$.

\section{KESIMPULAN DAN SARAN Kesimpulan}

a. Untuk aset investasi berupa surat utang korporasi atas nama BLT Finance BV, di mana diketahui bahwa nilai SAP-nya lebih kecil daripada SAK-nya, disebabkan aset tersebut memiliki peringkat di bawah peringkat $\mathrm{BBB}$, sehingga disarankan kepada pihak manajemen keuangan PT. Asuransi Jiwa Megalife agar memilih jenis investasi yang lebih menguntungkan bagi perusahaan dan emiten dalam melakukan investasi. Karena pengetahuan tentang hal tersebut merupakan salah satu faktor penting, di mana perusahaan dapat mengukur risiko kemungkinan dari emiten yang tidak dapat melakukan pembayaran kupon (bunga) atau pokok surat hutang tepat waktu (default risk) yang dapat diilihat dari peringkat obligasi yang dikeluarkan oleh agen pemeringkat obligasi (rating agency).

b. Untuk investasi lain berupa penyertaan syari'ah terdapat selisih dalam penilaian SAK dan SAP yaitu sebesar Rp. 27,500 juta, disebabkan aset ini tidak dimasukkan sebagai aset yang diperkenankan dalam perhitungan tingkat solvabilitas. Oleh sebab itu, disarankan kepada pihak manejemen keuangan PT. Asuransi jiwa Mega Life agar dapat mengalokasikan dana tersebut ke jenis investasi lain yang lebih menguntungkan dengan tetap menjaga optimalisasi return of investment dan mengendalikan risikonya.

c. Pihak manajemen keuangan PT. Asuransi Jiwa Megalife harus lebih cermat dan konservatif dalam memilih instrumen investasi yang akan dijalankan perusahaan, khususnya pada saham dan surat utang korporasi yang nilainya sangat berfluktuatif, sehingga dapat 
menghasilkan keuntungan bagi perusahaan. Pihak manajemen keuangan juga bisa melakukan diversifikasi dalam berinvestasi yaitu dengan mengalokasikan dana ke beberapa jenis investasi, misalnya deposito $20 \%$, obligasi $50 \%$, reksadana $25 \%$ dan saham $5 \%$. Sehingga jika terjadi suatu kegagalan dalam suatu instrumentasi investasi tertentu, perusahaan masih mempunyai dana dari investasi lainnya yang tidak mengalami kegagalan.

d. Pada Schedule F (Risiko Reasuransi) diketahui bahwa cadangan teknis beban reasuradur untuk reasuradur dalam pengawasan OJK lebih kecil jika dibandingkan reasuradur tidak dalam pengawasan OJK, yakni hanya sebesar $27.42 \%$, sedangkan pada reasuradur diluar pengawasan OJK menunjukkan 72,58\%, sehingga disarankan kepada pihak manajemen keuangan PT. Asuransi Jiwa Megalife agar memilih reasuradur yang mempunyai tingkat kinerja yang bagus dalam pengalihan risikonya.

e. Seperti yang kita ketahui bahwa Rasio pencapaian solvabilitas yang dicapai oleh Perusahaan Asuransi Jiwa Megalife periode 2016 cukup besar yaitu 670\%. Hal ini menunjukkan bahwa ada banyaknya dana yang belum didaya gunakan. Oleh karena itu, disarankan kepada pihak manajemen keuangan PT. Asuransi Jiwa Megalife agar bisa memanfaatkan atau mengelola kelebihan dana tersebut dengan baik, misalnya melakukan pengembangan usaha seperti penetrasi pasar, diversifikasi, dll dan berinvestasi dengan tetap menjaga optimalisasi return of investment dan mengendalikan risikonya.

\section{DAFTAR PUSTAKA}

Ayat, Safri.,2012, Pengantar Asuransi, Rizki Printing, Jakarta.

Dewan Standar Akuntansi Keuangan, 2010, Pernyataan Standar Akuntansi Keuangan No.36 (revisi 2011), Ikatan Akuntan Indonesia, Jakarta.

Jones, Harriett E. \& Long, Dani L., 2004, Prinsip-prinsip Asuransi Jiwa, Kesehatan, dan Anuitas, Life Office Management Association, Inc, Jakarta.
Jordan, Chester Wallace., 1991, Life Contingencies, The Society Of Actuaries, Chicago.

Kountur, Ronny., 2007, Metode Penelitian untuk Penulisan Skripsi dan Tesis, Percetakan Buana, Jakarta.

Muhammad, Abdulkadir., 2002, Hukum Asuransi Indonesia, Citra Aditya Bakti, Bandung.

Munawir, S. 2007, Analisa Laporan Keuangan, Liberty, Yogyakarta.

Peraturan Ketua Badan Pengawas Pasar Modal dan Lembaga Keuangan No. PER08/BL/2012, tentang Pedoman Perhitungan Modal Minimum Berbasis Risiko bagi Perusahaan Asuransi dan Perusahaan Reasuransi.

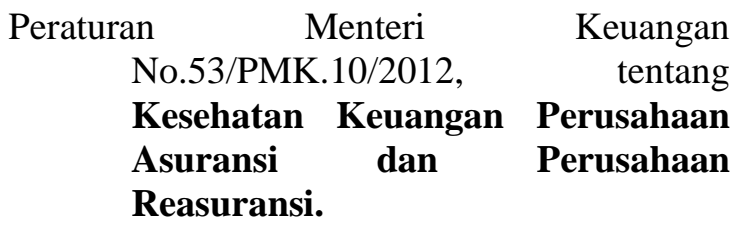

Salim, Abbas, 1998, Asuransi dan Manajemen Risiko, Raja Grafindo Persada, Jakarta.

Subekti, R. \& Tjibtrosudibio, R., 1991, Kitab Undang-undang Hukum Dagang dan Undang-Undang Kepailitan, PT. Pradnya Paramita, Jakarta.

Sugiyono., 2005, Metode Penelitian Bisnis, CV Alfabeta, Bandung.

Undang-Undang No 40 tahun 2014, tentang Usaha Perasuransian.

Walpole, Ronald E. \& Myers, Raymond H., 1995, Ilmu Peluang dan Statistika Untuk Insinyur dan Ilmuwan. Terj. R.K. Sembiring, ITB, Bandung.

www.ojk.go.id http://accountarona.blogspot.com/2011/05/ana lisis-laporan-keuangan.html http://www.bisnisasuransi.info/news_riskbase-capital 
